\title{
ARTICLE \\ Effect of subclinical mastitis on milk yield and milk composi- tion parameters in dairy camels
}

\author{
Leyla Hadef ${ }^{1,2 *}$, Brahim Hamad ${ }^{1,2}$, Hebib Aggad ${ }^{2}$ \\ 1 University of El Oued, Faculty of Life and Natural Sciences, Department of Agronomy, 39000 El Oued, Algeria \\ 2University of Tiaret, Institute of Veterinary Sciences, Laboratory of Hygiene and Animal Pathology, 14000 Tiaret, \\ Algeria
}

\section{ABSTRACT}

This study investigated the effects of subclinical mastitis on milk yield and milk composition parameters in dairy camels. A total of 140 camel milk samples were collected from multiparous she-camels (7-10 years old) and were subjected to bacteriological culture studies; 76 samples displayed subclinical mastitis and 64 samples were healthy. Furthermore, the samples were analyzed via standard procedures to determine the yield and composition parameters of the milk such as $\mathrm{pH}$, electrical conductivity, protein, fat, lactose, and ash content. The results showed that the milk yield was significantly low $(p<0.05)$ in infected animals compared to healthy animals ( $3.80 \mathrm{vs}$

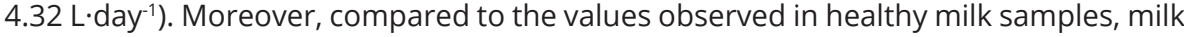
from animals with subclinical mastitis showed significantly decreased $(p<0.05)$ protein (3.33 vs $3.40 \%$ ) and fat (3.67 vs $3.74 \%$ ) contents. However, no significant changes ( $p>$ 0.05 ) were observed in $\mathrm{pH}$, electrical conductivity, lactose, or ash content. The results of the uninfected milk samples revealed that there was significant correlation between the protein and fat content $(r=0.781 ; p<0.01)$ and between the lactose and ash content $(r=$ $0.701 ; p<0.01)$. Conversely, the infected ones showed that there was higher significant correlation between the protein and fat contents $(r=0.807 ; p<0.01)$ and a medium correlation between the lactose and ash contents $(r=0.603 ; p<0.01)$. In conclusion, the results suggest that subclinical mastitis is negatively associated with a reduced milk yield and lower protein and fat content. Thus, these parameters can be used to diagnose mastitis in dairy camels.

Acta Biol Szeged 63(2):83-90 (2019)
\end{abstract}

\section{KEY WORDS}

camels

composition

milk yield

subclinical mastitis

\section{ARTICLE INFORMATION}

Submitted

3 November 2019

Accepted

12 December 2019.

*Corresponding author

E-mail: leila.hadef@yahoo.fr hadef-leyla@univ-eloued.dz

\section{Introduction}

Dromedary camels are considered the best livestock animals in arid, semiarid, and desert areas; camel milk is a valuable source of both nutrition and income in these areas (Saleh and Faye 2011; Ali et al. 2016; Legesse et al. 2017; Elbashir and Elhassan 2018). Camels can produce more milk for a longer period of time in arid zones and harsh environments than any other domestic livestock species (Seifu and Tafesse 2010; Eissa et al. 2011; Alluwaimi et al. 2017). Nevertheless, similar to other dairy animals, camels are affected by udder infections such as mastitis, which is a complex disease occurring worldwide among such animals. Heavy economic losses can occur as a result of clinical and subclinical mastitis (Toroitich et al. 2017; Gramay and Ftiwi 2018; Ali et al. 2019).

Mastitis, particularly the subclinical type, is one of the most persistent and widely spread disease condition that affect milk hygiene and quality among dairy camels (Husein et al. 2013; Hadef et al. 2016). The prevalence of subclinical mastitis in this species varies among different studies (15-67.4\%; Bhatt et al. 2004; Abera et al. 2010; Seifu and Tafesse 2010; Alamin et al. 2013). Subclinical mastitis causes the animal to suffer, reduces the milk yield, alters milk properties, impairs preservation and processing, and represents a public health concern for consumers of camel milk (Saleh and Faye 2011). In the same context, according to Fazlani et al. (2011), mastitis is known to cause a loss of approximately $70 \%$ of the camel milk production. Moreover, Ali et al. (2016) reported that subclinical mastitis modifies the composition of camel milk by decreasing the protein, fat, and lactose content; increasing enzymatic activity; and creating a higher electrical conductivity.

Therefore, many studies have been performed to investigate the effects of subclinical mastitis on milk yield and composition in other animal species. However, there are no reports in the literature regarding this association in camels. Thus, this study aimed to determine the impact of subclinical mastitis on milk yield and milk composition parameters in dairy camels. 


\section{Materials and methods}

\section{Study area}

This study was performed in a dairy farm located in Bir Naam, Southeast Algeria. This area is characterized by an arid climate with an average annual temperature of $21.8{ }^{\circ} \mathrm{C}$ and an average precipitation of $11.75 \mathrm{~mm}$. The rainy period begins at the start of September and lasts until May with a maximum of $19 \mathrm{~mm}$ of precipitation in November. The remainder of the year, pastures in the region are considered arid with an average maximum temperature of $33.6{ }^{\circ} \mathrm{C}$ and a very low precipitation of $2 \mathrm{~mm}$ in July. The vegetation commonly consists of steppe plants such as Stipa tenacissima and Ampelodesmos tenax.

\section{Animals}

The present study evaluated 140 milk samples obtained from multiparous healthy dairy she-camels. The animals were between 7 and 10 years old, with an average weight of 300 to $350 \mathrm{~kg}$ and an average milk yield of $4.04 \pm 0.10 \mathrm{~L} \cdot \mathrm{day}^{-1}$. All animals were maintained under the same conditions (grazing and supplementary farming systems). The animals were submitted to the same diet, which was primarily based on pasture (grass pasture system). The animals were supplemented with some barley concentrate and dry hay straw, with a higher intake during the dry season. The animals were hydrated regularly and hand-milked twice daily at 12-hour intervals. Calving generally occurs during the winter season and starts as early as November.

\section{Sample collection}

At the beginning of the experiment, all the camels were subjected to clinical examinations. The camels' udders were examined visually and by palpitation for the presence of any lesions by assessing redness, pain, heat, and swelling. Moreover, milk samples from each animal were obtained and assessed for any change in color and consistency. In this study, the 140 milk samples were collected just before the morning milking during the late stages of lactation. The teats were washed thoroughly and dried with a single-use paper towel. The first three streams of milk from each teat were discarded. The teat end and orifice were sanitized with cotton swabs soaked in $70 \%$ alcohol. The samples were collected from each animal in a sterile bottle. Furthermore, the milk samples were labeled, stored in an ice box, and transported immediately within 2-4 hours after collection to the laboratory for the bacteriological and physicochemical analyses.

\section{Milk analysis}

\section{Measurement of milk production}

Upon arrival to the laboratory, the quantity of the collected milk from each animal was measured with a graduated cylinder. The daily milk yield of the animals was the sum of the morning and evening milking.

\section{Bacteriological analysis}

The microbiological cultures were established according to the standard procedures of the National Mastitis Council (NMC 1987). All milk samples were used for the detection of specific bacteria that cause subclinical mastitis. For this purpose, a loopful of each milk sample was cultured on defibrinated sheep blood agar (7\%), nutrient agar, BCP (Bromcresol Purple Lactose) agar, and Chapman agar. Moreover, the plates were incubated at $37^{\circ} \mathrm{C}$ for $24-48$ hours. A sample was considered positive for subclinical mastitis when the growth of five or more identical colonies was detected on the streaks (Contreras et al. 1997; Pradieé et al. 2012). However, the growth of two or more different bacterial colonies (> 5 CFUs per type) was considered contamination, and the result was removed from the analysis (Gonzalo et al. 2002; Pradieé et al. 2012). The resulting growth was identified based on morphology, colony characteristics, Gram reaction, hemolytic characteristics, catalase test, and classic biochemical tests. Staphylococci and micrococci were identified based on their growth characteristics on triple sugar iron agar, mannitol salt agar, the nitrate reductase test, the urease test, the coagulase test, and the catalase test (Forbes et al. 2002; Quinn et al. 2011). Isolates that were tentatively identified as streptococci were evaluated according to their growth characteristics on the sheep blood agar, catalase production, and sugar fermentation tests. Gram-negative isolates were sub-cultured on BCP agar and were further tested using triple sugar iron agar, motility assessments, the IMViC test (Indole, Methyl red, Voges-Proskauer, and citrate utilization tests), and the urease test (Forbes et al. 2002; Quinn et al. 2011).

\section{Physical analysis}

The $\mathrm{pH}$ of the milk samples was determined using a pH-meter (Hanna HI 99161, Romania) equipped with a combined glass electrode after calibration in buffer solutions of $\mathrm{pH} 4$ and 7. Furthermore, the electrical conductivity was estimated with an electrical conductivity meter (Hanna EC 215) after the device was calibrated using standard buffer solutions.

\section{Chemical analysis}

The protein content was determined through quantification of the nitrogen content by the Kjeldahl method 
following the AOAC (2000). Nitrogen was then multiplied by a standard factor (6.38) so that the results were expressed as total protein content. The fat content was determined by the Gerber method according to the AOAC (2000). The lactose content was determined by Bertrand's method (AFNOR 1993). The ash content was determined by an AOAC (2000) technique using carbonization of the samples in a direct flame and subsequent calcination in a muffle at $550{ }^{\circ} \mathrm{C}$ for $4-6$ hours.

\section{Statistical analysis}

The data were analyzed using the Statistical Analysis System Program SPSS v.16.0. The model applied included the fixed effect of subclinical mastitis. Data are displayed in the tables as the mean \pm SEM. Differences in the mean values were tested using the independent-samples $T$ test or the Mann-Whitney U test after evaluating the normal distribution by the Shapiro-Wilk and Kolmogorov-Smirnov tests. Pearson's correlation test was used to interpret the relationship between the various studied parameters. A probability level $(p)$ of 0.05 was chosen as the limit for statistical significance in all tests.

\section{Results}

The effect of subclinical mastitis on milk yield and composition parameters is shown in Table 1 . Among the 140 samples analyzed, 76 were positive and 64 were negative. In addition, our study indicated that subclinical mastitis had a significant $(p<0.05)$ effect on milk yield $(3.80 \mathrm{vs}$
Table 1. Effect of subclinical mastitis on milk yield and composition parameters $(n=140)$.

\begin{tabular}{llll}
\hline Parameters & \multicolumn{2}{c}{ Means \pm SEM } & p-value \\
\cline { 2 - 3 } Number of samples & \multicolumn{1}{l}{ Healthy } & \multicolumn{1}{l}{ Infected } \\
\cline { 2 - 3 } & 64 & 76 & 0.023 \\
\hline Milk yield (L·day-1) & $4.32 \pm 0.14$ & $3.80 \pm 0.14$ & 0.220 \\
pH & $6.56 \pm 0.01$ & $6.53 \pm 0.01$ & 0.459 \\
EC (mS·cm-1) & $6.84 \pm 0.14$ & $6.98 \pm 0.13$ & 0.039 \\
Protein (\%) & $3.40 \pm 0.02$ & $3.33 \pm 0.02$ & 0.006 \\
Fat (\%) & $3.74 \pm 0.01$ & $3.67 \pm 0.01$ & 0.066 \\
Lactose (\%) & $4.20 \pm 0.04$ & $4.10 \pm 0.03$ & 0.064 \\
Ash (\%) & $1.02 \pm 0.02$ & $0.94 \pm 0.02$ & \\
\hline
\end{tabular}

EC: Electrical conductivity; SEM: standard error of mean. Means in the same row are significantly different $(p<0.05)$.

$4.32{\mathrm{~L} \cdot \text { day }^{-1}}^{-1}$, protein content (3.33 vs $\left.3.40 \%\right)$, and fat content (3.67 vs $3.74 \%$ ), with these parameters being significantly lower in the positive samples than in the negative samples $(p<0.05)$. However, no significant $(p$ $>0.05$ ) effect of subclinical mastitis was found on $\mathrm{pH}$, electrical conductivity, lactose, or ash contents.

The correlations between all of the studied parameters are reported in Table 2. In the healthy samples, the results showed that protein had a highly significant positive correlation with fat content $(r=0.781 ; p<0.01)$ and moderate positive correlation with ash $(r=0.264$; $p$ $<0.05)$. In comparison with the uninfected samples, the protein was significantly correlated with fat content $(r$ $=0.807 ; p<0.01)$, lactose $(r=0.343 ; p<0.01)$ and ash $(r$

Table 2. Relationship between the different studied parameters $(n=140)$.

\begin{tabular}{|c|c|c|c|c|c|c|}
\hline \multicolumn{7}{|c|}{ Healthy (64) } \\
\hline & $\mathrm{pH}$ & EC & Protein & Fat & Lactose & Ash \\
\hline Milk yield & -0.200 & -0.173 & -0.108 & -0.075 & -0.139 & -0.205 \\
\hline $\mathrm{pH}$ & & -0.147 & 0.032 & 0.147 & -0.067 & -0.011 \\
\hline EC & & & -0.084 & -0.176 & $0.275^{*}$ & 0.227 \\
\hline Protein & & & & $0.781 * *$ & 0.196 & $0.264^{*}$ \\
\hline Fat & & & & & 0.068 & 0.187 \\
\hline Lactose & & & & & & 0.701 ** \\
\hline \multicolumn{7}{|c|}{ Infected (76) } \\
\hline & $\mathrm{pH}$ & $\mathrm{EC}$ & Protein & Fat & Lactose & Ash \\
\hline Milk yield & 0.188 & 0.070 & 0.006 & -0.035 & 0.035 & 0.068 \\
\hline $\mathrm{pH}$ & & -0.049 & -0.077 & -0.061 & 0.044 & 0.005 \\
\hline EC & & & -0.020 & -0.126 & 0.162 & $0.295^{\star *}$ \\
\hline Protein & & & & $0.807^{* *}$ & $0.343 * *$ & $0.390 * *$ \\
\hline Fat & & & & & $0.348^{* *}$ & $0.299 * *$ \\
\hline Lactose & & & & & & $0.603 * *$ \\
\hline
\end{tabular}

$*: p<0.05 . * *: p<0.01$. All Pearson correlation coefficients are significant at $P<0.05$. 
$=0.390 ; p<0.01)$ in the infected samples. Moreover, a medium significant positive correlation was found in the samples with subclinical mastitis between fat and lactose $(r=0.348 ; p<0.01)$ and between fat and ash $(r=0.299 ; p$ $<0.01)$. Likewise, lactose was positively correlated with ash in the healthy samples $(r=0.701 ; p<0.01)$ and in the infected samples $(r=0.603 ; p<0.01)$. Similarly, the electrical conductivity showed significant positive correlations with lactose $(r=0.275 ; p<0.05)$ in the uninfected milk samples and with ash $(r=0.295 ; p<0.01)$ in the infected ones. Furthermore, in the healthy samples the milk yield was negatively correlated with all studied parameters; however, these relationships were not significant $(p>$ 0.05). Conversely, in the samples with subclinical mastitis the milk yield was negatively correlated with fat $(r$ $=-0.035 ; p>0.05$ ) only.

\section{Discussion}

Unlike clinical mastitis, which is responsible for high economic losses but easier to eliminate, subclinical mastitis is quite problematic because of its chronicity and relative incurability in dairy herds. Moreover, microbial infections alter the milk composition and render milk less suitable for consumption and processing.

In the present investigation, subclinical mastitis had a significant negative effect on milk yield. Such findings concur with previous reports in dairy cows (Tesfaye et al. 2010; Gonçalves et al. 2018), dairy goats (Pleguezuelos et al. 2015; Gelasakis et al. 2016; Hanuš et al. 2017), and dairy sheep (Marti De Olives et al. 2013). In these studies, a significantly lower milk yield was reported in mastitic animals than in non-mastitic animals. Nevertheless, no reports are available about the changes in the milk yield of mastitic she-camels. The decrease in the milk yield is attributed to the fact that mastitis is associated with mammary tissue damage, which reduces the number and activity of epithelial cells and consequently contributes to the decreased milk production (Zhao and Lacasse 2008).

The milk $\mathrm{pH}$ in our study was not affected by subclinical mastitis; this result differs from that of Ali et al. (2016), who mentioned that the $\mathrm{pH}$ of infected milk significantly increases in relation to the severity of the CMT reaction. According to Hadef et al. (2016), determining the $\mathrm{pH}$ of camel milk is not a suitable method for detecting subclinical mastitis in camels. The $\mathrm{pH}$ of milk may depend on other factors such as milk yield, lactation stage, milk composition, and the nature of fodder. In addition, the insignificant change in $\mathrm{pH}$ might also be due to the increased levels of citrates and bicarbonates during subclinical mastitis (Ogola et al. 2007).

Similarly, the electrical conductivity of the milk sam- ples did not differ significantly between healthy and infected milk in our study. This observation is in agreement with the findings of Eberlein (2007), who suggested that the electrical conductivity values in his study seem to be correlated in some camels with a positive CMT reaction but show no correlation to CMT and total bacterial counts or pathogenic bacteria in other camels or in the same camels on other days. Furthermore, several studies have demonstrated that electrical conductivity was not considered adequate as a method of diagnosing mastitis in camels (Younan et al. 2001; Bhatt et al. 2004; Eberlein 2007; Hadef et al. 2016). Contrary to the results of this study, Ali et al. (2016) found that the electrical conductivity of mastitic milk was significantly higher than that of milk obtained from healthy animals; they attributed their finding to the increased milk somatic cells. Moreover, the augmentation of electrical conductivity is due to the increased leakage of various ions and salts as a result of the increased permeability of vascular membranes following inflammatory reactions.

These contradictory results regarding the variation of electrical conductivity in relation to subclinical mastitis may be caused by breed differences, feeding, stage of lactation, parity number, and season. Furthermore, cell membrane permeability is altered during mastitis, which leads to the increased leakage of blood components into the udder and changes the milk composition (Sharif and Muhammad 2008).

In this study, the protein concentration decreased in the milk of she-camels affected with subclinical mastitis. Similarly, Eman Fathi et al. (2012) and Ali et al. (2016) reported that healthy she-camels produce milk with a higher protein percentage relative to mastitic camels (3.87 vs. $2.90 \%$, respectively). The change in protein may be explained by epithelial cell damage (decrease in synthesis) and an increase in vascular permeability with the passage of immunoglobulins, serum protein, and enzymes from the blood, which may lead to increased proteolysis (Forsbäck et al. 2010). Moreover, subclinical mastitis was associated with a decrease in milk fat percentage. These results are in agreement with other studies (Eman Fathi et al. 2012; Ali et al. 2016). The decrease in fat percentage seems to be a result of a decrease in the synthesis and secretion activities of mammary glands (Le Maréchale al. 2011). It is also important to note that variations in the fat percentage can be affected by the stage of lactation (Abdalla et al. 2015; Hadef et al. 2018), genetics, management, season (Shuiep et al. 2008), and geographic location (Konuspayeva et al. 2009).

Data in the literature regarding the effect of subclinical mastitis on the total concentration of milk protein and fat in other animal species (cows, goats, and sheep) are very conflicting. Some authors sustain that there is a decrease 
of these parameters in mastitis cases (Yarabbi et al. 2014; Barrón-Bravo et al. 2013; Bianchi et al. 2004), whereas others report an increase of these parameters (Guariglia et al. 2015; Pleguezuelos et al. 2015; Olechnowicz et al. 2010). By contrast, other studies have reported that subclinical mastitis has no significant influence on protein and fat contents in milk (Hachana et al. 2018; Ying et al. 2002; Summer et al. 2012).

The current study showed that there is an inverse but non-significant relationship between the values of lactose and subclinical mastitis $(p>0.05)$. Our result is consistent with previous reports on camel milk (Eman Fathi et al. 2012). Moreover, Ali et al. (2016) agree that there is a reduction in the concentration of lactose in milk obtained from animals with subclinical mastitis; however, their results were significant. According to Leitner et al. (2011), the lactose concentration in milk closely reflects both the reduction in milk yield and the deterioration of milk's ability to curdle. Furthermore, the decrease in lactose content can be explained by a decreased capacity for synthesis of the disaccharide by the mammary gland or an increase in the $\mathrm{NaCl}$ concentration in the milk, resulting in osmotic disruption in the gland and sugar deprivation by bacteria (Rysanek and Babak 2005).

In addition, according to the literature, factors other than mastitis can also influence the milk lactose content. In the same context, Aljumaah et al. (2012) found that the lactose percentage in camel milk is significantly influenced by the management system, breed parity, and stage of lactation. The present results indicate that the concentrations of ash obtained from infected and healthy she-camels were not significantly different $(p>0.05)$. This finding is in agreement with the results reported by Alemu et al. (2013) who indicated that there was no significant difference in the concentrations of ash in cattle. This finding can be attributed to the relationship between the ash content and the electrical conductivity, which are intimately linked. Consequently, these two parameters did not display significant variation in our study (Kaikci et al. 2012).

The significant positive correlation observed in the present study in the uninfected and infected milk samples between protein and fat contents agreed with the results of previous studies (Musaad et al. 2013; Elobied et al. 2015; Nagy et al. 2017). Similarly, Konuspayeva et al. (2010) sustain that the correlation between protein and fat is widely described in other dairy animals. Moreover, the significant relationship found in the two groups between the other parameters included in this study was in agreement with the results of Musaad et al. (2013) and Elobeid et al. (2015), except for the positive significant correlations observed between electrical conductivity and lactose in the uninfected samples and ash in the infected ones. In the same context, Musaad et al. (2013) reported a significant negative correlation of electrical conductivity with lactose and ash, whereas Elobeid et al. (2015) declared that there was no significant correlation between the previous parameters. According to Eberlein (2007), the relationship observed between electrical conductivity and ash in the samples with subclinical mastitis in this study can be explained by damage caused to the udder parenchyma cell membranes in mastitis cases. The increase of the permeability of the barrier between blood and milk occurred due to an increase in the contents of chloride $\left(\mathrm{Cl}^{-}\right)$and sodium $\left(\mathrm{Na}^{+}\right)$, which leads to a higher electrical conductivity of milk. In addition, unlike our study, Nagy et al. (2017) found a negative correlation between fat and lactose concentrations.

Moreover, the current study revealed that the correlations between the all studied parameters and milk yield in the healthy samples were negative, which was in agreement with previous reports (Musaad et al. 2013; Elobied et al. 2015; Nagy et al. 2017). The observed negative correlation between milk production and other milk components can be attributed to the dilution effect due to the changing milk quantity that had been described earlier. In contrast, in the infected samples the milk yield was negatively correlated only with fat content. This finding can be explained by the significant decrease of the quantity of milk produced by the infected animals; thus, the dilution effect was attenuated in this case.

In conclusion, this study showed that the subclinical infection of mammary glands had a statistically significant negative effect on the milk yield, protein, and fat contents in dairy camels. Therefore, monitoring changes in these parameters is a suitable method for the diagnosis of subclinical mastitis in this species. However, no significant influence of subclinical mastitis was found on $\mathrm{pH}$, electrical conductivity, lactose, and ash content. Therefore, this study indicates that subclinical mastitis is a significant cause of deterioration of important milk components, which has an economic impact on the productivity of this animal species.

\section{Acknowledgments}

The authors are very much thankful to the camel farm owners for agreement to participate in this study.

\section{References}

Abdalla EB, Ashmawy AEHA, Farouk MH, Salama OAR, Khalil FA, Seioudy AF (2015) Milk production potential in Maghrebi she-camels. Small Rum Res 123:129-135. 
Abera M, Abdi O, Abunna F, Megersa B (2010) Udder health problems and major bacterial causes of camel mastitis in Jijiga, Eastern Ethiopia: implication for impacting food security. Trop Anim Health Prod 42:341-347.

AFNOR (1993) Association Française de Normalisation: Contrôle de la qualité des produits alimentaires, Lait et produits laitiers. AFNOR ed, Paris.

AOAC (2000) Association of Official Agricultural Chemists: Official Methods of Analysis, $17^{\text {th }}$ ed. Washington, DC, AOAC International.

Alamin MA, Alqurashi AM, Elsheikh AS, Yasin TE (2013) Mastitis incidence and bacterial causative agents isolated from lactating she-camel (Camelus dromedaries). IOSR J Agric Vet Sci 2:7-10.

Alemu S, Tamiru F, Almaw G, Tsega A (2013) Study on bovine mastitis and its effect on chemical composition of milk in and around Gondar Town, Ethiopia. J Vet Med Anim Health 5:215-221.

Ali M, Avais M, Ijaz M, Chaudhary M, Hussain R, Aqib AI, Khan NU, Sohail ML, Khan M, Khan MA, Ahmad M, Hasni MS, Qaiser I, Rashid G, Haq I, Khan I (2019) Epidemiology of Subclinical Mastitis in Dromedary Camels (Camelus dromedarius) of Two Distinct Agro-Ecological Zones of Pakistan. Pak J Zool 51:527-532.

Ali F, Hussain R, Qayyum A, Gul ST, Iqbal Z, Hassan MF (2016) Milk somatic cell counts and some hematobiochemical changes in sub-clinical mastitic dromedary she-camels (Camelus dromedarius). Pak Vet J 36:405-408.

Aljumaah RS, Almutairi FF, Ismail E, Alshaikh MA, Sami A, Ayadi M (2012) Effects of production system, breed, parity, and stage of lactation on milk composition of dromedary camels in Saudi Arabia. J Anim Vet Adv 11:141-147.

Alluwaimi AM, Al Mohammad Salem KT, Al-Ashqar RA, Al-Shubaith IH (2017) The Camel's (Camelus Dromedarius) Mammary Gland Immune System in Health and Disease. J Adv Dairy Res 5:1-6.

Barrón-Bravo OG, Gutiérrez-Chávez AJ, Ángel-Sahagún CA, Montaldo HH, Shepard L, Valencia-Posadas M (2013) Losses in milk yield, fat and protein contents acccording to different levels of somatic cell count in dairy goats. Small Rum Res 113:421-431.

Bhatt L, Chahar A, Tuteja FC, Verma D (2004) Prevalence, etiology and antibiogram of subclinical mastitis isolates from camel. Vet Pract 5:61-65.

Bianchi L, Bolla A, Budelli E, Caroli A, Casoli C, Pauselli M, Duranti E (2004) Effect of udder health status and lactation phase on the characteristics of Sardinian ewe milk. J Dairy Sci 87:2401-2408.

Contreras A, Corrales JC, Sanchez A, Sierra D (1997) Persistence of subclinical intramammary pathogens in goats throughout lactation. J Dairy Sci 80:2815-2819.

Eberlein V (2007) Hygienic status of camel milk in Dubai
(United Arab Emirates) under tow different milking management systems. Dissertation Thesis. University of München, Germany.

Eissa EA, Yagoub AEA, Babiker EE, Ahmed IAM (2011) Physicochemical, Microbiological and Sensory Characteristics of Yoghurt Produced from Camel Milk During Storage. Electron J Environ Agric Food Chem 10:23052313.

Elbashir MHM, Elhassan SF (2018) Seasonal Effect on Camel Milk Composition (Camelus dromedaries) Under Traditional and Intensive Management Systems in Butana Area-Sudan. Am Sci Res J Eng Tech Sci 39:197-205.

Elobied AA, Osman AM, Abu Kashwa SM, Ali AS, Ibrahim MT, Salih MM (2015) Effect of parity and breed on some physico-chemical components of Sudanese camel milk. Res Opin Anim Vet Sci 5:20-24.

Eman Fathi M, Raghib RW, Saudi AM, El-Essawy HA (2012) Chemical and microbiological assessment of raw camel's milk with special reference to subclinical mastitis monitoring in Egypt. Assiut Vet Med J 58:1-15.

Fazlani SA, Khan SA, Faraz S, Awan MS (2011) Antimicrobial susceptibility of bacterial species indentified from mastitic milk samples of camel. Afr J Biotechnol 10:2959-2964.

Forbes BA, Sahm DF, Weissfield AS (2002) Bailey and Scotts Diagnostic Microbiology. $11^{\text {th }}$ ed. Mosby Inc, Missouri.

Forsbäck L, Lindmark-Mansson H, Andrén A, SvennerstenSjaunja K (2010) Evaluation of quality changes in udder quarter milk from cows with low-to-moderate somatic cell count. Animal 4: 617-626.

Gelasakis AI, Angelidis AS, Giannakou R, Filioussis G, Kalamaki MS, Arsenos G (2016) Bacterial subclinical mastitis and its effect on milk yield in low-input dairy goat herds. J Dairy Sci 99:3698-3708.

Gonçalves JL, Kamphuis C, Martins CMMR, Barreiro JR, Tomazi T, Gameiro AH, Hogeveen H, Dos Santos MV (2018) Bovine subclinical mastitis reduces milk yield and economic return. Livest Sci 210:25-32.

Gonzalo C, Ariznabarreta A, Carriedo JA, San Primitivo F (2002) Mammary Pathogens and their relationship to somatic cell count and milk yield losses in dairy Ewes. J Dairy Sci 85:1460-1467.

Gramay S, Ftiwi M (2018) Camel Milk Production, Prevalence and Associated Risk Factors of Camel Mastitis Inaysaita Woreda Afar Regional State, North East Ethiopia. ARC J Anim Vet Sci 4:17-37.

Guariglia BAD, Dos Santos PA, De Souza Araújo L, Giovannini CI, Neves RBS, Nicolau ES, Da Silva MAP (2015) Effect of the somatic cell count on physicochemical components of milk from crossbred cows. Afr J Biotechnol 14:1519-1524.

Hachana Y, Znaidi A, M'Hamdi N (2018) Effect of somatic cell count on milk composition and mozzarella cheese 
quality. Acta Aliment 47:88-96.

Hadef L, Aggad H, Hamad B, Mahmoud MS, Adaika A (2016) Subclinical mastitis in dairy camels in Algeria: Comparison of screening tests. Acta Agric Slov 108:85-92.

Hadef L, Aggad H, Hamad B, Saied M (2018) Study of yield and composition of camel milk in Algeria. Scientific Study \& Research Chemistry \& Chemical Engineering, Biotechnology, Food Industry 19:1-11.

Hanuš O, Roubal P, Kučera J, Klimešová M, Jedelská R, Kopecký J (2017) Somatic cell count and milk yield losses in goats. Acta Univ Agric Silvic Mendelianae Brun 65: 1149-1160.

Husein A, Haftu B, Hunde A, Tesfaye A (2013) Prevalence of camel (Camelus dromedaries) mastitis in Jijiga Town, Ethiopia. Afr J Agric Res 8:3113-3120.

Kaikci G, Cetin O, Bingol EB, Gunduz MC (2012) Relations between electrical conductivity, somatic cell count, California mastitis test and some quality parameters in the diagnosis of subclinical mastitis in dairy cows. Turk J Vet Anim Sci 36:49-55.

Konuspayeva G, Faye B, Loiseau G (2009) The composition of camel milk: a meta-analysis of the literature data. J Food Compos Anal 22:95-101.

Konuspayeva G, Faye B, Loiseau G, Narmuratova M, Ivashchenko A, Meldebekova A, Davletov S (2010) Physiological change in camel milk composition (Camelus dromedarius) 2. Physicochemical composition of colostrums. Trop Anim Health Prod 42:501-505.

Legesse A, Adamu F, Alamirew K, Feyera T (2017) A Comparative Study on the Physicochemical Parameters of Milk of Camel, Cow and Goat in Somali Regional State, Ethiopia. Chem Sci J 8:4.

Leitner G, Merin U, Silanikove N (2011) Effects of glandular bacterial infection and stage of lactation on milk clotting parameters: Comparison among cows, goats and sheep. Int Dairy J 21:279-285.

Le Maréchal C, Thiéry R, Vautor E, Le Loir Y (2011) Mastitis impact on technological properties of milk and quality of milk products-a review. Dairy Sci Technol 91:247-282.

Marti De Olives A, Díaz JR, Molina MP, Peris C (2013) Quantification of milk yield and composition changes as affected by subclinical mastitis during the current lactation in sheep. J Dairy Sci 96:7698-7708.

Musaad AM, Faye B, Al-Mutairi SE (2013) Seasonal and physiological variation of gross composition of camel milk in Saudi Arabia. Emir J Food Agric 25:618-624.

Nagy P, Fábri N, Varga L, Reiczigel J, Juhász J (2017) Effect of genetic and nongenetic factors on chemical composition of individual milk samples from dromedary camels (Camelus dromedarius) under intensive management. J Dairy Sci 100:8680-8693.

NMC (1987) Laboratory and Field Handbook on Bovine Mastitis. National Mastitis Council Inc., Madison.
Ogola H, Shitandi A, Nanua J (2007) Effect of mastitis on raw milk compositional quality. J Vet Sci 8: 237-242.

Olechnowicz J, Sobek Z, Jakowski JM, Antosik P, Bukowska D (2010) Connection of somatic cell count and milk yield as well as composition in dairy ewes. Arch Tierz 53:95-100.

Pleguezuelos FJ, De La Fuente LF, Gonzalo C (2015) Variation in Milk Yield, Contents and Incomes According to Somatic Cell Countin a Large Dairy Goat Population. J Adv Dairy Res 3: 145.

Pradieé J, Moraes CR, Gonçalves M, Vilanova MS, Corrêa GF, Lauz OG, Osorio MTM, Schmidt V (2012) Somatic cell count and California castitis cest as a diagnostic tool for subclinical mastitis in ewes. Acta Sci Vet 40: 1038.

Quinn PJ, Markey BK, Leonard FC, Hartigan P, Fanning S, FitzPatrick ES (2011) Veterinary Microbiology and Microbial Disease. $2^{\text {nd }}$ ed. John Wiley and Sons Ltd, Chicester, UK.

Rysanek D, Babak V (2005) Bulk tank milk somatic cell count as an indicator of the hygiene status of primary milk production. J Dairy Res 72:400-405.

Saleh SK, Faye B (2011) Detection of subclinical mastitis in dromedary camels (Camelus dromedarius) using somatic cell counts, California mastitis test and udder pathogen. Emir J Food Agric 23:48-58.

Seifu E, Tafesse B (2010) Prevalence and etiology of mastitis in traditionally managed camels (Camelus dromedarius) in selected pastoral areas in eastern Ethiopia. Ethiop Vet J 14:103-113.

Sharif A, Muhammad G (2008) Somatic cell count as an indicator of udder health status under modern dairy production: A review. Pak Vet J 28:194-200.

Shuiep ES, El Zubeir IEM, El Owni OAO Musa HH (2008) Influence of season and management on composition of raw camel (Camelus dromedarius) milk in Khartoum State, Sudan. Trop Subtrop Agroecosyst 8:101-106.

Summer A, Malacarne M, Sandri S, Formaggioni P, Mariani P, Franceschi P (2012) Effects of somatic cell count on the gross composition, protein fractions and mineral content of individual ewe milk. Afr J Biotechnol 11:16377-16381.

Tesfaye GY, Regassa FG, Kelay B (2010) Milk yield and associated economic losses in quarters with subclinical mastitis due to Staphylococcus aureus in Ethiopian crossbred dairy cows. Trop Anim Health Prod 42:925-931.

Toroitich KC, Gitau GK, Kitala PM, Gitao GC (2017) The prevalence and causes of mastitis in lactating traditionally managed one-humped camels (Camelus dromedarius) in West Pokot County, Kenya. Livest Res Rural Dev 29: Article 62.

Yarabbi H, Mortazavi A, Mehraban M, Sepehri N (2014) Effect of somatic cells on the physic-chemical and microbioal properties of raw milk in different seasons. Int J Plant Anim Environ Sci 4:289-298. 
Ying C, Wang HT, Hsu JT (2002) Relationship of somatic cell count, physical, chemical and enzymatic properties to the bacterial standard plate count in dairy goat milk. Liv Prod Sci 17:63-77.

Younan M, Ali Z, Bornstein S, Muller W (2001) Application of California mastitis test in intra mammary Streptococcus agalactiae and Staphylococcus aureus infection of camels (Camelus dromedaries) in Kenya. Prev Vet Med 51:307-316. Zhao X, Lacasse P (2008) Mammary tissue damage during bovine mastitis: causes and control. J Anim Sci 86:57-65. 